good fortune to have Mr Brian Hargreaves as illustrator. I cannot recommend it too highly. But she does make one mistake. She is describing the many remarkable entomological achievements of the Rothschild family. Among these she names the Checked Skipper Inn at Ashton Wold, built by the Hon N C Rothschild, as "the only pub in England named after a butterfly." She should visit the new town of Harlow where she will discover no fewer than 18 pubs named after butterflies and moths. The butterflies are the white admiral, the essex skipper, the painted lady, the small copper, and the purple emperor. The moths include the garden tiger, the drinker, the heart and club, and my old friend the hummingbird hawk. Anyone seriously infected with the entomological bug will need a journal. The two I have found most useful, and incidentally recommended to me by Sir Cyril
Clarke, are the Bulletin of the Amateur Entomolists' Society, and the Entomologist's Record and fournal of Variation.

But the best guide of all is the book of nature itself in the shape of a garden, half of which is devoted to the shrubs and plants that attract butterflies. Among the shrubs are buddleia, spiraea, blackthorn, hawthorn, honeysuckle, the tree lupin, and the orinary bramble or blackberry. Among the plants are valerian, nettles, hops, the various kinds of vetch, dog violets, heartsease and the other wild pansies, primroses, cowslips, clover, rape, lucerne charlock, jack-by-the-hedge, the everlasting pea, and wild thyme. You cannot have a butterfly garden without a good crop of weeds. What better excuse could there be for not weeding.

PS. 16 July. Today the first comma for eight years arrived in our garden. I knew it was going to be a good year for butterflies.

\title{
The game of cricket
}

\author{
H M SINCLAIR
}

The practice of medicine is much older than the game of cricket. It took man some time to discover that it might be fun to defend a couple (initially) of sticks with a third across the top by wielding a fourth against a piece of rock thrown along the ground. This discovery may have been made in the Weald of Kent, and the first probable reference to cricket comes from the wardrobe accounts of Edward $I$ in 1300 in that county. At the beginning of the sixteenth century Gargantua indulged in 217 games listed by Rabelais, including cricket; since he was provided with a carpet this seems to be the first use of matting - used to this day, for the equivalent of Lord's in South Africa is the Wanderers' ground in Johannesburg, the pitch being matting laid on ant-heaps.

Boys protecting a target with a weapon against a missile graduated to the most enjoyable form of the game-carefree village cricket and its elder brother club cricket, reaching its zenith in Butterflies, I Zingari, Free Foresters, Incogniti, and others. An obvious evolution was for counties to play one another, starting with Kent's challenge to the Londoners in 1707. And since boys must be dragooned by pedagogues, school cricket teams evolved, Eton and Harrow first playing at Lord's in 1808 with Byron despite lameness in the latter's team. A game taken too seriously is ruined, and "the flannelled fools at the wicket" became heroes not just in the wide eyes of small boys but even in the side glances of their masters, so that Kipling could write of these:

How is this reason (which is their reason) to judge a scholar's worth

By casting a ball at three straight sticks and defending the same with a fourth?

How different from village cricket! Here the blacksmith (alias garage mechanic) will be clouting the slow bowling of the doctor, while the publican and the vicar are carrying a barrel into the pavilion. I recall a glorious day at Stow-onthe-Wold when the village policeman beat a ball into the long grass, and while it was sought among the cow-pats the

International Nutrition Foundation, International Institute of Human Nutrition, Sutton Courtenay, Abingdon, Oxon OX14 4AW H M SINCLAIR, FRCP, director wicket-keeper told him the bowler was H G O Owen-Smith, who had just been playing in the Test Match for South Africa against England. The PC got out next ball. Dr "Tuppy" OwenSmith is one of the best players the medical profession has produced. Indeed, he has a remarkable record to his name since, although primarily a bowler, he made 129 for South Africa against England at Leeds in 1929, sharing with A J Bell a 10th wicket partnership of 103, which still stands as a record against any country. He also played for Middlesex. Australia has produced Dr George $\mathrm{R}$ Thomas (former surgical registrar at St George's), who opened against the West Indies in 1951.

\section{W G Grace}

Our profession must take pride in having produced the greatest cricketer of all time. W G Grace (1848-1915) was the fourth of five sons of a doctor near Bristol, to the medical school of which he went before qualifying from Bart's and the Westminster. He practised as a surgeon in Bristol from 1879 . $\mathrm{He}$ was chosen to play for the Gentlemen v Players when only 16, and at Lord's helped his side to their first victory for 13 years. $\mathrm{He}$ played in the first Test Match in this country against Australia in 1880, making 152 . He last played for England in 1899 when 50 years and 320 days old, gave up surgical practice the same year, and retired to be manager of cricket at the Crystal Palace. In his later cricketing days massive, rugged, and unwashed, he has many records still standing, and his eminence may be shown by comparison with achievements of Frank Woolley.

\begin{tabular}{lccccccc}
\hline & $\begin{array}{c}\text { Years in } \\
\text { 1st-class } \\
\text { cricket }\end{array}$ & Runs & Av & Wickets & Av & $\begin{array}{c}1000 \\
\text { runs } \\
100 \\
\text { wickets }\end{array} \begin{array}{c}2000 \\
\text { runs } \\
\text { wickets }\end{array}$ \\
\hline W G Grace & 44 & 54896 & $39 \cdot 55$ & 2876 & 17.99 & 8 & 2 \\
F E Woolley & 33 & 58969 & 40.75 & 2068 & 19.85 & 8 & 4 \\
\hline
\end{tabular}

Grace, apart from a longer spell in first-class cricket (until 1908 when aged 60) had a bowling advantage over Woolley, who gave up long before he ceased to bat complaining of stiffness (never apparent to me when I was coached by him); Grace, 
usually captain, kept himself on with what was often thought to be undue optimism. He also when bowled first ball replaced the bails remarking: "All these people have come to see me bat."

\section{Doctors against the Lawyers}

A recent medical Test player is C B ("Bertie") Clarke (b 1918) of Barbados, who played for the West Indies in 1939 and also played for Northants and Essex. He, like "Tuppy" OwenSmith, enjoyed club cricket, and his bowling was a great strength for the Doctors against the Lawyers. This regular annual event lapsed, but in 1977 the Law Society Cricket Club approached the BMA through Dr Elston Grey-Turner with a challenge, passed on to me. Last year's game was the fourth played on the Magdalen Ground (which from 1851 to 1881 was rented by the university before it moved to the parks). On paper we are stronger than on the field. We cannot use the great surgeon Sir William Spurgeon-great (Auden and Isherwood inform us in A Dog Beneath the Skin) because he captained his hospital. Some of our distinguished players do not seem to have the resilience of W G Grace. We have not had the practical help of Lord Smith, Dr R A Shaddick (who played for Middlesex), Dr Ian Thwaites (of Sussex), Dr Hughie Webb (of St Thomas's), Professor Sir John Butterfield (who captained Oxford at cricket and hockey as well as being a rugger Blue, but now graces some other university), or Dr Thomas Hunt (once a superb wicketkeeper, whose death two years ago was a grievous loss to his many friends, and who came to support us in our first three games).

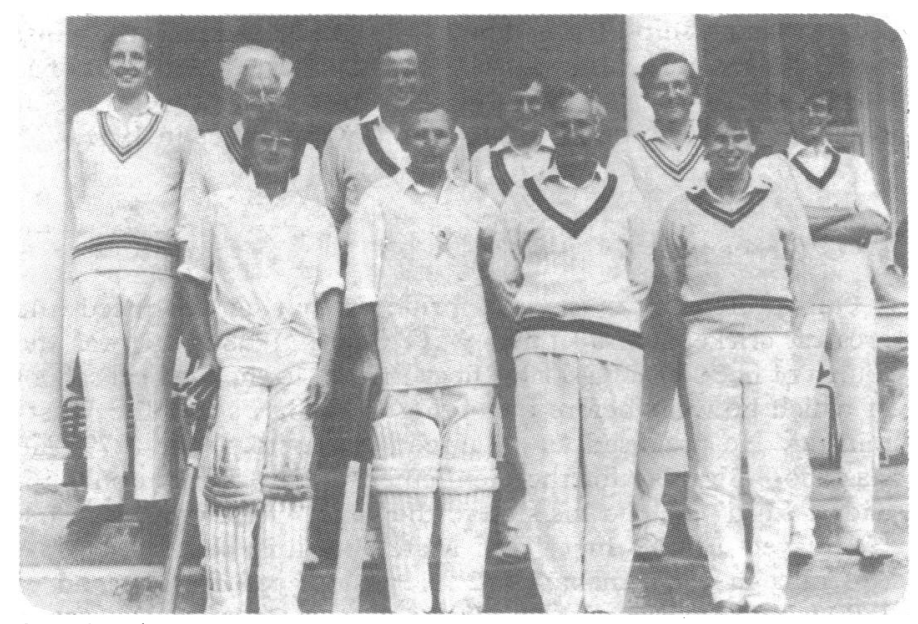

The victorious 1981 team

But last year we defeated the Lawyers on 5 July. They won the toss and batted first. We took the field under Alastair Hunter, who opened with the excellent left-arm bowling of Sean Hilton who rapidly clean bowled two (including Gerry Williams, the enthusiastic hon match secretary and captain of the Law Society). The indefatigable Michael Goldacre bowled fast from the other end and had the opening batsman well caught by Tim Huins in the slips. When another batsman was clean bowled by Hilton the score was five for 35 , but now it rapidly doubled as the sixth wicket hit fiercely until number 5 was caught at square leg off Hilton by Goldacre, who had been replaced by Geoffrey Cook's slow right-arm bowling. When Hilton was replaced by the slow left-arm bowling of Huins the innings rapidly closed for 100 runs. Hilton in 16 overs had five for 27, Goldacre in 10 overs one for 28, Cook in 13 overs two for 23, but statistically no-one could better Tim Huins' average of zero coming from one wicket in four maiden overs.

A massive lunch, well lubricated, had been taken when the Lawyers were 74 for six. We felt confident of passing the target of 100 but disaster struck. Richard Jowett, playing on a ground familiar to him when an undergraduate cricket and golf Blue, was out third ball for 0 , and Tim Huins was lbw for two with only 10 on the board. Tim Goodwin hit three splendid boundaries before being caught, making the score three for 14 . Not good enough. Roger Moss had started confidently if cautiously, but the Nuffield professor of surgery, Peter Morris, changed the course of the game when he with Moss had a spirited stand of 34 before Moss was caught for 20 off Gerry Williams, whose accurate slow bowling had looked dangerous, and he bowled Geoffrey Cook for five. That brought in David Farrow at six for 66, still 35 short of victory. But Peter Morris looked invincible until he was stumped when attacking Williams, having scored 38, which was the highest on either side. Michael Goldacre had no chance to show what an attacking batsman he can be because David Farrow crowned his excellent wicket-keeping by securing victory with an unbeaten 23 , bringing the total to 103 for six. That enthusiastic veteran Alastair Hunter was deprived of his innings, as were Sean Hilton and Ian Hall. But most important, there was adequate time for celebrating the victory in the pavilion.

\section{As it should be played}

This is cricket as it should be played. A Shropshire Lad advised us that "Ale, man, ale's the stuff to drink for fellows whom it hurts to think," or:

\section{Now in Maytime to the wicket Out I march with bat and pad: \\ See the son of grief at cricket Trying to be glad. \\ Try I will; no harm in trying; Wonder 'tis how little mirth \\ Keeps the bones of man from lying On the bed of earth.}

But in an Almanac last century Kipling struck a happier note.

Thank God who made the British Isles
And taught me how to play,
I do not worship crocodiles,
Or bow the knee to clay!
Give me a willow wand and I
With hide and cork and twine
From century to century
Will gambol round my shrine!

Any intelligent person who has read as far as this may wonder why I reported last year's game. Well, this year we lost by five wickets, but no matter: we enjoy our encounter with the Law. 